
ISSN : 2615-1995, E-ISSN : 2615-0654

J. Madani., Vol. 3, No. 2, September 2020 (267 - 276)

(C)2018 Lembaga Kajian Demokrasi

dan Pemberdayaan Masyarakat (LKD-PM)

DOI : https://doi.org/10.33753/madani.v3i2.117

\title{
Analisis Pengaruh Kepemilikan Institusional, Kepemilikan Manajerial, Pertumbuhan Perusahaan, dan Ukuran Perusahaan Terhadap Kebijakan Utang
}

\author{
Intan Rahma Sari \\ Fakultas Ekonomi, Universitas Pamulang \\ dosen02419@unpam.ac.id
}

\begin{abstract}
Abstrak
Tujuan Penelitian ini adalah untuk menguji pengaruh Kepemilikan Institusional, Kepemilikan Manajerial, Pertumbuhan Perusahaan dan Ukuran Perusahaan terhadap Kebijakan Utang (Studi Empiris Perusahaan Perbankan Yang Terdaftar di Bursa Efek Indonesia Tahun 2012-2016). Metode/Pendekatan Data dalam penelitian ini merupakan data sekunder berbentuk data panel. Data sekunder di dapatkan secara tidak langsung dari objek atau subjek penelitian. Data panel merupakan data gabungan antara data runtut waktu dan data silang. Hasil penelitian, Variabel Kepemilikan Institusional (Inst) terbukti menunjukkan nilai positif. Penelitian ini berhasil membuktikan bahwa kepemilikan institusional memiliki pengaruh positif namun tidak signifikan terhadap kebijakan utang perusahaan. Hal ini memungkinkan, jika perusahaan menggunakan hutang dalam jumlah yang besar untuk mendanai proyek yang berisiko tinggi, maka kemungkinan kegagalan bisa terjadi, oleh karena itu pemegang saham institusional dapat langsung menjual saham yang dimilikinya. Variabel Kepemilikan Manajerial terbukti menunjukkan nilai negatif. Hal ini dikarenakan Kepemilikan saham oleh manajemen memiliki hubungan kausal negatif dan substitusi dengan hutang. Variabel Pertumbuhan Perusahaan membuktikan bahwa kebijakan utang menunjukkan nilai negatif. Penelitian ini berhasil membuktikan bahwa pertumbuhan perusahan memiliki pengaruh negatif yang tidak signifikan terhadap kebijakan utang perusahaan. Pertumbuhan perusahaan dapat dilihat dari total aktiva, tidak semuanya berasal dari hutang. Variabel Ukuran perusahaan (LN) terbukti menunjukkan nilai negatif. Penelitian ini berhasil membuktikan bahwa ukuran perusahaan memiliki pengaruh negatif tidak signifikan terhadap kebijakan utang perusahaan. Simpulan penelitian, Kepemilikan Institusional, Kepemilikan Manajerial dan Pertumbuhan Perusahaan berpengaruh tidak signifikan dan hasil signifikan didapat pada ukuran perusahaan terhadap kebijakan utang. Kepemilikan Institusional, Kepemilikan Manajerial, Pertumbuhan Perusahaan dan Ukuran Perusahaan secara bersama-sama berpengaruh tidak signifikan terhadap kebijakan utang.
\end{abstract}

Kata Kunci : Kepemilikan Institusional, Manajerial, Pertumbuhan dan Ukuran Perusahaan

\begin{abstract}
The purpose of this study was to examine the effect of Institutional Ownership, Managerial Owner ship, Company Growth and Company Size on Debt Policy (Empirical Study of Banking Companies Listed on the Indonesia Stock Exchange in 2012-2016). Method/Approach The data in this study is secondary data in the form of panel data. Secondary data is data obtained not directly from the object or subject of research. Panel data is a combination of time series data and cross data. The results of, Institutional Ownership Variable proved to show a positive value. This research has proven that institutional ownership has a positive but not significant effect on corporate debt policy. This is because if the company uses a large amount of debt to fund high-risk projects, has the possibility of failure, then the institutional shareholders can immediately sell their shares. Managerial Ownership Variables are shown to show negative values. This is because share ownership by management has
\end{abstract}


a negative causal relationship and substitution with debt. The Company's Growth Variable is proven by its debt policy showing a negative value. Company growth has a negative but not significant effect on corporate debt policy. Company size has a negative but significant influence on corporate debt policy. The conclusions of the study, Institutional Ownership, Managerial Ownership and Corporate Growth influence but not significant and significant results obtained on the size of the company on debt policy. Institutional ownership, managerial ownership, company growth and company size jointly influence but not significantly to debt policy.

Keywords : Institutional Ownership, Managerial, Company Growth and Size

\section{PENDAHULUAN}

Dalam struktur perusahaan, komponen terpenting sebuah perusahaan ada pada system pendanaan perusahaan. Kebijakan yang digunakan dalam pendanaan perusahaan haruslah bertujuan untuk memaksimalkan kemakmuran perusahaan. Dalam hal ini, pendanaan harus mempertimbangkan dan menganalisis sumbersumber dana yang ekonomis guna membiayai kebutuhan dan investasi bagi perusahaan. Sumber pendanaan bisa di dapat dari modal sendiri yaitu dengan menggunakan laba ditahan, selain itu perusahaan juga bisa mendapatkan sumber dana dari kreditur dengan menggunakan kebijakan hutang. "Hutang merupakan komponen yang tidak terpisahkan dari sebuah perusahaan." (Rifai, 2015).

Persaingan dalam dunia bisnis dan ekonomi telah membuat perusahaan berusaha meningkatkan nilai perusahaan. Perusahaan didirikan dengan berbagai tujuan, dan memliki target pencapaian dalam bisnis. Tujuan utamanya adalah "untuk memaksimalkan kemakmuran dan keuntungan bagi para pemegang sahamnya." (Brigham dan Houston, 2006). Salah satu cara untuk mencapai tujuan perusahaan adalah dengan meningkatkan nilai dan mutu perusahaan tersebut. Tujuan lain dari perusahaan yaitu mendapatkan laba dari tahun ke tahun untuk menjaga keberlangsungan hidup perusahaan. Berkaitan dengan keberlangsungan hidup perusahaan tersebut, salah satu keputusan yang dihadapi oleh manajer keuangan adalah keputusan sumber pendanaan. Keputusan sumber pendanaan yaitu "suatu keputusan keuangan yang berkaitan dengan komposisi modal dan utang." (Syafiudin, 2013).

Kebijakan utang termasuk dalam kebijakan pendanaan perusahaan yang bersumber dari eksternal. Modigliani dan Miller (1963) menyatakan bahwa "semakin tinggi proporsi utang maka semakin tinggi nilai suatu perusahaan." Hal ini berkaitan dengan adanya keuntungan yang berasal dari pengurangan pajak karena adanya bunga yang dibayarkan akibat penggunaan utang, hal tersebut mengurangi penghasilan yang terkena pajak. Manajer harus mengambil keputusan bisnis terbaik untuk meningkatkan kemakmuran pemilik dan para pemegang saham sehingga tujuan utama perusahaan dalam meningkatkan nilai perusahaan dapat tercapai. (Brigham dan Houston, 2006).

Penunjukan manajer oleh pemegang saham untuk mengelola perusahaan, oleh Jensen dan Meckling (1976) dalam bathala et al. (1994). Penunjukan digunakan sebagai pemisahan fungsi decision making dan risk beating.

Oleh karena itu, tujuan dari penelitian ini adalah untuk menguji kembali variabel yang memiliki hasil yang berbeda agar dapat mendapatkan hasil yang memperkuat penelitian sebelumnya.

\section{METODE}

Data dalam penelitian ini menggunakan data sekunder berbentuk data panel. Data sekunder diperoleh secara tidak langsung dari objek atau subjek penelitian. Data panel adalah data gabungan antara data runtut waktu (time series) dan data silang (cross section).

Sesuai dengan data yang diperlukan yaitu data sekunder, maka metode pengumpulan data dalam penelitian ini adalah dengan menggunakan tehnik dokumentasi yang berdasarkan laporan keuangan periode 2012 sampai 2016 yang dipublikasikan oleh BEI melalui download di internet ( $w w w . i d x$. co.id), mengambil dari artikel, jurnal, penelitian 
terdahulu, mempelajari buku-buku pustaka yang mendukung penelitian terdahulu dan proses penelitian serta pengungkapan dalam berita bisnis, pengungkapan emiten dan sumber-sumber lain yang relevan. Data yang diperlukan yaitu terkait dengan Kepemilikan Institusional, Pertumbuhan Perusahaan, Ukuran Perusahaan, dan Kebijakan Hutang.

\section{HASIL dan PEMBAHASAN}

\section{Landasan Teori}

\section{Teori Keagenan (Agency Theory)}

Teori Agency diambil dari buku, dalam pemaparannya oleh Michael C. Jensen dan William H. Meckling pada tahun 1976, menjelaskan bahwa masalah agensi timbul dikarenakan adanya perbedaan kepentingan antara manajemen sebagai agensi dan pemegang saham sebagai prinsipal. Pemegang saham menginginkan tingkat pengembalian yang cepat dan sebesar mungkin atas investasi yang dilakukan, sedangkan manajemen cenderung menginginkan keuntungan serta insentif yang memadai dan sebesar-besarnya atas kinerja mereka.

Menurut Wahidahwati (2002: 3) "penyebab lain konflik antara manajemen dan pemegang saham adalah keputusan pendanaan." Para pemegang saham hanya peduli pada risiko sistematis dari saham perusahaan sedangkan manajemen peduli pada risiko perusahaan secara keseluruhan. Masalah tersebut dapat menimbulkan biaya agensi, karena pemegang saham mengeluarkan biaya untuk mengawasi kinerja manajer, sehingga perusahaan akan menurunkan keuntungan yang diterima oleh pemegang saham. Menurut Murni dan Andriana (2007: 16) "ada beberapa pendekatan yang dapat dilakukan untuk mengurangi biaya agensi antara lain" : 1. Meningkatkan kepemilikan manajerial. Adanya keterlibatan kepemilikan saham akan membuat manajer bertindak secara hati-hati, karena mereka ikut menanggung konsekuensi atas keputusan yang diambilnya, 2. Meningkatkan monitoring agent melalui kepemilikan institusional. Adanya kepemilikan oleh institusi lain seperti perusahaan investasi, bank dan perusahaan asuransi maupun berupa ke- pemilikan lembaga lain akan mendorong munculnya pengawasan yang lebih optimal terhadap kinerja manajemen, 3. Meningkatkan dividend payout ratio, sehingga tidak tersedia cukup banyak free cash flow dan manajemen terpaksa mencari pendanaan dari luar untuk membiayai investasinya dan 4. Meningkatkan pendanaan dengan hutang. Peningkatan hutang akan menurunkan konflikkeagenan dan menurunkan excess cash flow yang ada dalam perusahaan, sehingga menurunkan kemungkinan pemborosan oleh manajemen.

\section{Teori Pecking Order (Pecking Order Theory)}

Menurut Saidi (2004: 46) pecking order theory pertama kali dikemukakan oleh Gordon Donaldson pada tahun 1961. Pecking order theory menyatakan bahwa perusahaan lebih memilih untuk menggunakan sumber dana dari dalam atau pendanaan internal daripada pendanaan eksternal. Dana internal tersebut diperoleh dari laba ditahan yang dihasilkan dari kegiatan operasional perusahaan. Jika pendanaan eksternal diperlukan maka perusahaan akan memilih dimulai dari sekuritas yang paling aman yaitu hutang yang paling rendah risikonya kemudian turun ke hutang yang lebih berisiko, sekuritas hybrid seperti obligasi konversi, saham preferen dan yang terakhir saham biasa.

Menurut Saidi (2004: 47) "pendanaan internal lebih disukai daripada pendanaan eksternal karena pendanaan internal memungkinkan perusahaan tidak membuka diri lagi dari sorotan pemodal luar sedangkan pendanaan eksternal lebih disukai dalam bentuk hutang daripada modal sendiri yaitu saham karena dua alasan." Pertama adalah pertimbangan biaya emisi dimana biaya emisi obligasi lebih murah dibanding biaya emisi saham baru. Kedua, manajer khawatir jika menerbitkan saham baru akan memberikan sinyal kabar buruk kepada investor dan membuat harga saham menurun karena disebabkan adanya informasi asimetri antara pihak investor dan pihak manajemen.

\section{Trade off Theory}

Teori ini mengungkapkan bahwa pengguna- 
an utang diatas 100 persen sulit dijumpai. Kenyataannya semakin banyak utang, maka semakin tinggi beban yang harus ditanggung. Satu hal yang penting bahwa dengan meningkatnya utang, maka semakin tinggi probabilitas kebangkrutan. "Beban yang harus ditanggung saat menggunakan utang yang lebih besar adalah biaya kebangkrutan, biaya keagenan, beban bunga yang semakin besar dan sebagainya." (Syafiudin H, 2013).

\section{Pengembangan Hipotesis \\ Kepemilikan Institusional Terhadap Kebijakan Utang}

Dalam agency theory, manajer bertindak sesuai dengan keinginan pemegang saham (principal) atau dalam hal ini investor. Hal ini karena manajer tidak mempunyai wewenang untuk menentukan kebijakan perusahaan. Manajer hanya bertugas menjalankan kebijakan perusahaan sesuai keinginan pemegang saham (principal).

Wewenang tertinggi berada di tangan pemilik saham. Prinsipipal atau investor terbagi menjadi institusi maupun perorangan. Institusi yang memiliki saham biasa disebut kepemilikan institusional. Kepemilikan institusional (lembaga/ perusahaan) umumnya bertindak sebagai pihak yang memonitor perusahaan. Peningkatan aktivitas investor didukung oleh usaha untuk meningkatkan tanggung jawab manajemen. "Aktivitas pengawasan tersebut dapat dilakukan dengan menempatkan para komite penasehat yang bekerja untuk melindungi kepentingan investor." (Susanto, 2011). Semakin tinggi kepemilikan institusional perusahaan, maka akan semakin kecil hutang yang digunakan untuk mendanai perusahaan. Hal ini disebabkan karena timbulnya suatu pengawasan oleh lembaga institusi lain (bank dan asuransi) terhadap kinerja perusahaan. "Apabila perusahaan menggunakan hutang dalam jumlah yang besar untuk mendanai proyek yang berisiko tinggi, mempunyai kemungkinan kegagalan, oleh sebab itu pemegang saham institusional tersebut dapat langsung menjual saham yang dimilikinya." (Yeniatie dan Destriana, 2010). Hasil penelitian Nuraina (2012) menyimpulkan bahwa Kepemilikan Institusional berpengaruh terhadap kebijakan utang. Berdasarkan uraian tersebut, maka dapat dibuat hipotesis sebagai berikut:

H1 : Kepemilikan institusional memiliki pengaruh positif terhadap kebijakan utang.

\section{Kepemilikan Manajerial \\ Terhadap Kebijakan Utang}

Jensen et al. (1992) menyimpulkan bahwa insider ownership berpengaruh negatif terhadap tingkat Hutang atau debt. Moh'd et al. (1998) menyimpulkan bahwa "struktur kepemilikan (percent insiders ownership, shareholders dispersion, dan percent institusional investors) mempunyai pengaruh yang signifikan dan berhubungan negatif dengan rasio hutang perusahaan." Friend dan Lang (1988) menunjukkan bahwa "kepemilikan saham oleh manajemen memiliki hubungan kausal negatif dan substitusi dengan hutang." Kim dan Sorenson (1986) menjelaskan bahwa "pada perusahaan-perusahaan yang sahamnya dimiliki oleh sebagian besar oleh manajemen, membutuhkan hutang yang lebih banyak." Putri dan Nasir (2006), Fadah dan Novi (2008) menyimpulkan bahwa kepemilikan manajerial mempunyai pengaruh negatif signifikan terhadap kebijakan hutang.

Adanya perbedaan kepentingan antara prinsipal dan agen akan selalu menjadi konflik yang terus terjadi dalam perusahaan. Pihak prinsipal fokus terhadap kesejahteraan pribadinya melalui pembagian dividen yang diperoleh. Sedangkan pihak agen akan komisi atas kerja kerasnya dalam menjalankan operasional perusahaan.

Tujuan ini terkadang saling berlawanan. Pihak pemilik sering kali tidak dapat merealisasikan dividen atas modal ketika perusahaan dibawah kontrol manajemen setelah telah menggunakan hutang yang relatif tinggi. Kas seharusnya dibagikan menjadi dividen justru digunakan membayar hutang beserta bunganya. Dari sinilah konflik kepentingan mulai terjadi.

Dalam menyelaraskan kepentingan kedua belah pihak maka langkah yang bisa diambil salah satunya dengan peningkatan kepemilikan saham oleh pihak manajerial. Dengan peningkatan ini diharapkan pihak manajemen juga akan merasa memiliki perusahaan serta merasakan langsung akibat atas pengambilan keputusan yang 
kurang tepat. Hasil Penelitian Hidayat (2013) menyimpulkan bahwa kepemilikan manajerial berpengaruh terhadap kebijakan utang.

H2 : Kepemilikan manajerial berpengaruh positif terhadap kebijakan utang

\section{Pertumbuhan Perusahaan}

\section{Terhadap Kebijakan Utang}

Perusahaan yang mencapai pertumbuhan yang tinggi pasti membutuhkan modal, salah satunya dengan menjual saham di bursa saham atau pasar modal. Dalam pecking order theory, perusahaan akan mencari sumber dana dari eksternal dengan memprioritaskan hutang apabila sumber dana dari eksternal masih kurang mencukupi. Perusahaan yang memiliki tingkat pertumbuhan yang tinggi cenderung membutuhkan dana dari sumber eksternal yang lebih besar. Untuk memenuhi kebutuhan dana dari luar, perusahaan dihadapkan pada pertimbangan sumber dana yang lebih murah. Penerbitan surat hutang lebih disukai dibandingkan dengan mengeluarkan saham baru, karena biaya emisi (penerbitan) saham baru lebih besar dari pada biaya hutang. (Indahningrum dan Destriana, 2010).

Suatu perusahaan yang mengalami pertumbuhan yang tinggi berarti perusahaan tersebut berhasil meningkatkan nilai perusahaan untuk menghasilkan keuntungan/laba. Perusahaan yang mempunyai pertumbuhan yang tinggi menunjukkan bahwa dengan sumber daya yang dimiliki bisa menghasilkan pertumbuhan yang baik. Perusahaan dengan tingkat pertumbuhan yang tinggi akan lebih memaksimalkan penggunaan sumber daya yang dimiliki. (Hardiningsih dan Oktaviani, 2012). Menurut Rodoni dan Ali (2014) menyatakan bahwa pertumbuhan perusahaan secara tidak langsung berpengaruh pada pendanaan ekuitas yang signifikan walaupun pada keadaan dimana biaya kebangkrutan rendah. Jadi perusahaan dengan pertumbuhan tinggi akan memiliki debt ratio yang lebih rendah dibandingkan dengan perusahaan yang pertumbuhannya rendah.

Tingkat pertumbuhan yang tinggi, belum tentu menggunakan hutang untuk memenuhi kebutuhan dana. Pertumbuhan perusahaan dilihat dari bertambahnya aktiva, tidak semuanya berasal dari hutang, karena perusahaan lebih cenderung untuk menghindari resiko dalam berhutang apabila perusahaan tidak mampu melunasinya (Susanto, 2011). Hasil penelitian ade (2015) menyimpulkan bahwa pertumbuhan perusahaan tidak berpengaruh terhadap kebijakan hutang. Berdasarkan uraian tersebut, maka dapat dibuat hipotesis sebagai berikut:

H3 : Pertumbuhan perusahaan memiliki pengaruh negatif terhadap kebijakan hutang.

\section{Ukuran Perusahaan Terhadap Kebijakan Utang}

Dalam pecking order theory, perusahaan lebih memprioritaskan sumber pendanaan dari dalam perusahaan (laba ditahan). Semakin besar perusahaan tersebut, maka semakin banyak dana yang digunakan untuk menjalankan operasional perusahaan, salah satu sumber dananya adalah dengan berhutang. Ukuran perusahaan menjadi faktor yang perlu dipertimbangkan dalam menentukan tingkat hutang perusahaan.

Menurut Gitman dan Zutter (2012) Ukuran perusahaan adalah "besarnya aset perusahaan yang memungkinkan tingkat leverage perusahaan besar akan lebih besar dari perusahaan yang lebih kecil." Dari uraian tersebut dapat disimpulkan bahwa ukuran kecil perusahaan akan mempengaruhi struktur modal didasarkan pada kenyataan bahwa semakin besar suatu perusahaan akan memiliki tingkat pertumbuhan yang tinggi, sehingga perusahaan lebih bersedia untuk mengeluarkan saham baru dan juga cenderung menggunakan jumlah pinjaman akan meningkat. Hal ini didukung penelitian yang dilakukan oleh Akoto dan Awunyo-Vitor (2013) menemukan bahwa ukuran perusahaan berpengaruh positif dan signifikan terhadap kebijakan hutang.

Perusahaan besar cenderung lebih mudah memperoleh pinajaman dari pihak ketiga, hal ini karena kemampuan mengakses ke pihak lain atau jaminan yang dimiliki berupa aktiva bernilai lebih besar dibandingkan perusahaan kecil (Susanto, 2011). Hasil penelitian Hidayat (2013) menyimpulkan bahwa ukuran perusahaan berpengaruh positif pada kebijakan hutang Berdasarkan uraian tersebut, maka dapat dibuat hipotesis sebagai berikut: 
H4 : Ukuran perusahaan memiliki pengaruh positif terhadap kebijakan hutang

\section{Kepemilikan Institusional \\ Terhadap Kebijakan Utang}

Variabel Kepemilikan Institusional (KI) menunjukkan koefisien regresi positif sebesar 0.003791. Probabilitas menunjukkan nilai yang lebih besar dari 0,05 yaitu 0.9427 . Hal ini berarti bahwa tingkat signifikansinya lebih besar $a$ $=5 \%$, sehingga hipotesis ke- 1 tidak di dukung atau $\mathrm{H}_{0}$ diterima. Penelitian ini berhasil membuktikan bahwa kepemilikan institusional berpengaruh tidak signifikan terhadap kebijakan utang perusahaan. Hal ini disebabkan, Apabila perusahaan menggunakan hutang dalam jumlah yang besar untuk mendanai proyek yang berisiko tinggi, maka perusahaan mempunyai kemungkinan kegagalan, dalam hal ini pemegang saham institusional dapat langsung menjual saham yang dimilikinya. Hasil penelitian ini mendukung penelitian Nuraina (2012), Kepemilikan Institusional berpengaruh terhadap kebijakan utang yang menunjukkan bahwa kepemilikan institusional berpengaruh positif terhadap kebijakan hutang.

\section{Kepemilikan Manajerial}

\section{Terhadap Kebijakan Utang}

Variabel Kepemilikkan Manajerial (KM) menunjukkan koefisien regresi negatif sebesar -0.025606. Probabilitas menunjukkan nilai lebih besar dari 0,05 yaitu 0.4425 . Hal ini berarti bahwa tingkat signifikansinya lebih besar $\alpha=5 \%$, sehingga hipotesis ke-2 tidak didukung atau $\mathrm{H}_{0}$ diterima. Penelitian ini berhasil membuktikan bahwa kepemilikkan manajerial berpengaruh tidak signifikan terhadap kebijakan utang perusahaan. Kepemilikkan saham oleh manajemen memiliki hubungan kausal negatif dan substitusi dengan hutang. Hasil penelitian ini tidak mendukung penelitian Hidayat (2013) dimana kepemilikan manajerial berpengaruh terhadap kebijakan utang.

\section{Pertumbuhan Perusahaan \\ Terhadap Kebijakan Utang}

Variabel Pertumbuhan Perusahaan (PP) menunjukkan koefisien regresi negatif sebesar -0.066717. Probabilitas menunjukkan nilai lebih besar dari 0,05 yaitu 0.1557 . Hal ini berarti bahwa tingkat signifikansinya lebih besar $\alpha=5 \%$, sehingga hipotesis ke-3 tidak didukung atau $\mathrm{H}_{0}$ diterima. Penelitian ini berhasil membuktikan bahwa pertumbuhan perusahan berpengaruh tidak signifikan terhadap kebijakan utang perusahaan. Pertumbuhan perusahaan dengan bertambahnya aktiva tidak semuanya berasal dari hutang, karena perusahaan lebih cenderung untuk menghindari resiko apabila tidak mampu melunasinya hutangnya. (Susanto, 2011). Hasil penelitian ini mendukung penelitian ade (2015), dimana pertumbuhan perusahaan tidak berpengaruh terhadap kebijakan hutang.

\section{Ukuran Perusahaan Terhadap Kebijakan Utang}

Variabel Ukuran Perusahaan (UP) menunjukkan koefisien regresi negatif sebesar -0.009922. Probabilitas menunjukkan nilai lebih kecil dari 0,05 yaitu 0.0245 . Hal ini berarti bahwa tingkat signifikansinya lebih kecil $\alpha=5 \%$, sehingga hipotesis ke-4 berhasil didukung atau $\mathrm{H}_{0}$ ditolak. Penelitian ini berhasil membuktikan bahwa ukuran perusahaan berpengaruh signifikan terhadap kebijakan utang perusahaan. Semakin besar perusahaan tersebut, maka semakin banyak dana yang digunakan untuk menjalankan operasional perusahaan. Hasil penelitian ini mendukung penelitian Hidayat (2013) dimana Ukuran perusahaan berpengaruh positif pada kebijakan hutang.

\section{Kepemilikan Institusional, Kepemilikan Manajerial, Pertumbuhan Perusahaan, dan Ukuran Perusahaan Secara Bersama-sama Terhadap Kebijakan Utang}

Variabel KI, KM, PP, dan UP pada tabel regresi data panel menunjukkan nilai $\mathrm{f}_{\text {hitung }}$ sebesar 2,243851 dimana dalam $\mathrm{f}_{\text {tabel }}$ nilai tersebut < 2,6896 . Secara bersama-sama variabel independen memiliki nilai Prob (f-stat) 0,087849 dimana nilai tersebut lebih besar dari 0,05 , sehingga variabel 
independen secara bersama-sama memiliki pengaruh namun tidak signifikan.

\section{Hasil Analisis dan Pembahasan \\ Kepemilikkan Institusional \\ Terhadap Kebijakan Utang}

Variabel KI menunjukkan koefisien regresi positif sebesar 0.003791. Probabilitas menunjukkan nilai yang lebih besardari 0,05 yaitu 0.9427. Hal ini berarti bahwa tingkat signifikansinya lebih besar $\alpha=5 \%$, sehingga hipotesis ke-1 tidak didukung atau $\mathrm{H}_{0}$ diterima. Penelitian ini berhasil membuktikan bahwa kepemilikan institusional berpengaruh tidak signifikan terhadap kebijakan utang perusahaan. Hal ini disebabkan Apabila perusahaan menggunakan hutang dalam jumlah yang besar untuk mendanai proyek yang berisiko tinggi, mempunyai kemungkinan kegagalan, maka pemegang saham institusional tersebut dapat langsung menjual saham yang dimilikinya. Hasil penelitian ini mendukung penelitian Nuraina (2012), Kepemilikan Institusional berpengaruh terhadap kebijakan utang yang menunjukkan bahwa kepemilikan institusional berpengaruh positif terhadap kebijakan hutang.

\section{Kepemilikan Manajerial Terhadap Kebijakan Utang}

Variabel KM menunjukkan koefisien regresi negatif sebesar -0.025606 . Probabilitas menunjukkan nilai lebih besar dari 0,05 yaitu 0.4425. Hal ini berarti bahwa tingkat signifikansinya lebih besar $\alpha=5 \%$, sehingga hipotesis ke-2 tidak didukung atau $\mathrm{H}_{0}$ diterima. Penelitian ini berhasil membuktikan bahwa kepemilikan manajerial berpengaruh tidak signifikan terhadap kebijakan utang perusahaan. Kepemilikan saham oleh manajemen memiliki hubungan kausal negatif dan substitusi dengan hutang. Hasil penelitian ini tidak mendukung penelitian Hidayat (2013), dimana kepemilikan manajerial berpengaruh terhadap kebijakan utang.

\section{Pertumbuhan Perusahaan \\ Terhadap Kebijakan Utang}

Variabel PP menunjukkan koefisien regresi negatif sebesar -0.066717 . Probabilitas me- nunjukkan nilai lebih besar dari 0,05 yaitu 0.1557. Hal ini berarti bahwa tingkat signifikansinya lebih besar $\alpha=5 \%$, sehingga hipotesis ke-3 tidak didukung atau $\mathrm{H}_{0}$ diterima. Penelitian ini berhasil membuktikan bahwa pertumbuhan perusahan berpengaruh tidak signifikan terhadap kebijakan utang perusahaan. Pertumbuhan perusahaan dengan bertambahnya aktiva tidak semuanya berasal dari hutang, karena perusahaan lebih cenderung untuk menghindari resiko apabila tidak mampu melunasinya (Susanto, 2011). Hasil penelitian ini mendukung penelitian Ade (2015), dimana pertumbuhan perusahaan tidak berpengaruh terhadap kebijakan hutang.

\section{Ukuran Perusahaan Terhadap Kebijakan Utang}

Variabel UP menunjukkan koefisien regresi negatif sebesar -0.009922. Probabilitas menunjukkan nilai lebih kecil dari 0,05 yaitu0.0245. Hal ini berarti bahwa tingkat signifikansinya lebih kecil $\alpha=5 \%$, sehingga hipotesis ke- 4 berhasil didukung atau $\mathrm{H}_{0}$ ditolak. Penelitian ini berhasil membuktikan bahwa ukuran perusahaan berpengaruh signifikan terhadap kebijakan utang perusahaan. Semakin besar perusahaan tersebut, maka semakin banyak dana yang digunakan untuk menjalankan operasional perusahaan. Hasil penelitian ini mendukung penelitian Hidayat (2013) dimana Ukuran perusahaan berpengaruh positif pada kebijakan hutang.

\section{Kepemilikkan Institusional, Kepemilikkan Manajerial, Pertumbuhan Perusahaan, dan Ukuran Perusahaan Secara Bersama-sama Terhadap Kebijakan Utang}

Variabel KI, KM, PP, dan UP pada tabel regresi data panel menunjukkan nilai $\mathrm{f}_{\text {hitung }}$ sebesar 2,243851 dimana dalam $\mathrm{f}_{\text {tabel }}$ nilai tersebut < 2,6896. Secara bersama-sama variabel independen memiliki nilai Prob (f-stat) 0,087849 dimana nilai tersebut lebih besar dari 0,05 , sehingga variabel independen secara bersama-sama memiliki pengaruh namun tidak signifikan.

\section{SIMPULAN}

Variabel Kepemilikkan Institusional (Inst) 
terbukti menujukkkan nilai positif. Penelitian ini berhasil membuktikan bahwa kepemilikkan institusional memiliki pengaruh positif namun tidak signifikan terhadap kebijakan utang perusahaan. Hal ini disebabkan Apabila perusahaan menggunakan hutang dalam jumlah yang besar untuk mendanai proyek yang berisiko tinggi, mempunyai kemungkinan kegagalan, maka pemegang saham institusional tersebut dapat langsung menjual saham yang dimilikinya.

Variabel Kepemilikan Manajerial (Man) terbukti menunjukkan nilai negatif. Penelitian ini berhasil membuktikan bahwa kepemilikan manajerial memiliki pengaruh negatif namun tidak signifikan terhadap kebijakan utang perusahaan. Hal ini dikarenakan Kepemilikan saham oleh manajemen memiliki hubungan kausal negatif dan substitusi dengan hutang.

Variabel Pertumbuhan Perusahaan (Growth) terbukti kebijakan utang menunjukkan nilai negatif. Penelitian ini berhasil membuktikan bahwa pertumbuhan perusahan memiliki pengaruh negatif namun tidak signifikan terhadap kebijakan utang perusahaan. Pertumbuhan perusahaan dengan bertambahnya aktiva tidak semuanya berasal dari hutang, karena perusahaan lebih cenderung untuk menghindari resiko apabila tidak mampu melunasinya (Susanto, 2011).

Variabel Ukuran perusahaan (LN) terbukti menunjukkan nilai negatif. Penelitian ini berhasil membuktikan bahwa ukuran perusahaan memiliki pengaruh negatif namun signifikan terhadap kebijakan utang perusahaan. Hal ini dikarenakan Semakin besar perusahaan tersebut, maka semakin banyak dana yang digunakan untuk menjalankan operasional perusahaan.

Dalam penelitian selanjutnya pelaksanaan operasional perusahaan sebaiknya mengurangi proporsi pendanaan dari hutang sehingga dapat mengurangi financial distress, karena pendanaan dari hutang perusahaan menyebabkan financial distress dan agency cost lebih besar dibandingkan dengan penghematan pajak dari beban bunga utang, akibatnya perusahaan sangat rentan terhadap gejolak perekonomian selain itu pengembangan informasi terkait kebijakan utang pada perusahaan perbankan juga dapat dilakukan pada penelitian selanjutnya.

\section{PENGHARGAAN}

Terima kasih yang sebesar-besarnya kepada berbagai pihak yang telah memberikan dukungan kepada penulis dalam penyelesaian penelitian ini, terutama kepada:

1. Bapak DR. (HC) Darsono selaku Ketua Yayasan Sasmita Jaya yang telah memberikan dukungan moril dan materiil kepada penulis sehingga dapat terselesaikan tepat waktu.

2. Bapak DR. H. Endang Ruhiyat,. S.E., M.M., CSRA., CMA Selaku Dekan Akuntansi Universitas Pamulang.

3. Ibu Effriyanti, S.E., M.M., Akt., M.Si., CA., Selaku Ketua Program Studi Akuntansi Universitas Pamulang.

4. Bapak Dr. J. Sumarno, M.M., Ak., Selaku Pembimbing 1 dalam penelitian ini.

5. Bapak Prof. Dr. Adji Suratman, CA, CPMA, CPA, Ak. Selaku Pembimbing 2 dalam penelitian ini

6. Keluarga tercinta yang selalu mendukung, memotivasi dan memberikan perhatiannya dengan tanpa pamrih.

7. Semua Pihak yang telah membantu dan mendukung penulis dalam menyelesaikan penelitian ini yang tidak dapat disebutkan satu persatu.

\section{DAFTAR PUSTAKA}

Bahri, S. (2017). Pengaruh Kepemilikan Manajerial, Kebijakan Dividen, Profitabilitas, Ukuran Perusahaan dan Arus Kas Bebas (Free Cash Flow) Terhadap Kebijakan Hutang. Jurnal Penelitian Teori dan Terapan Akuntansi, 2(2). e-ISSN 2528-2581.

Barus, S. R. dan A. C. (2018). Kebijakan Hutang Pada Perusahaan Sektor Utama Yang Terdaftar Di Bursa Efek Indonesia Periode 20132016. Jurnal Akuntansi, 8(2), 127-138. ISSN 2622-6421.

Brigham, E. F., dan J. F. Houston. (2001). Manajemen Keuangan. Edisi Bahasa Indonesia. Jakarta: Erlangga.

Chariri, I. G. dan A. (2014). Teori Akuntansi (4th 
ed). Semarang: Badan Penerbit Universitas Diponerogo.

Fahmi, I. (2014). Manajemen Keuangan Perusahaan dan Pasar Modal. Edisi Pertama. Jakarta.

Fidiana, Z. Y. P. (2017). Pengaruh Arus Kas Bebas, Profitabilitas dan Ukuran Perusahaan Terhadap Kebijakan Utang. 6 (3), 1126-1147. ISSN 2460-0585.

Friend, I., dan Lang, H.P. (1988). An Empirical Test of The Impact of Managerial Self-interest on Corporate Capital Structureî. Journal of Finance. Vol. 43, P. 271-282.

G. Agustian, W. Y. (2014). Pengaruh Kepemilikan Manajerial, Kepemilikan Institusional, dan Kebijakan Dividen Terhadap Kebijakan Utang Perusahaan (Studi pada perusahaan Property, Real Estate, \& Building Construction yang terdaftar di Bursa Efek Indonesia Tahun 2010-2013). 1(3), 203. ISSN 2355-9357.

Ghozali, I dan Chariri, A. (2007). Teori Akuntansi. Semarang: BP UNDIP.

Ghozali, I. dan Ratmono, D. (2013). Analisis Multivariat dan Ekonometrika, Teori, Konsep dan Aplikasi dengan Eviews 8. Semarang: BP UNDIP.

Ghozali, I. (2016). Aplikasi Analisis Multivariate dengan Program IBM SPSS 23 (Edisi 8). Cetakan ke VIII. Semarang: Badan Penerbit Universitas Diponegoro.

Ghozali, I. (2018). Aplikasi Analisis Multivariate dengan Program IBM SPSS 25 (9th ed). Semarang: Badan Penerbit Universitas Diponegoro.

Harahap, S. S. (2014). Analisis Kritis atas Laporan Keuangan. Edisi 1-10. Jakarta: Rajawali Pers.

Haryono, S. (2005). Struktur kepemilikan Dalam Bingkai Teori Keagenan, Jurnal Akuntansi dan Bisnis,Vol. 5, No. 1, Hlm. 63-71.

Indahningrum, R. P dan Handayani, R. (2009). "Pengaruh Kepemilikan Manajerial, Kepemilikan Insitusional, Dividen, Pertumbuhan Perusahaan, Free Cash Flow, dan Profitabilitas terhadap Kebijakan Hutang Perusahaan”. Jurnal Bisnis dan Akuntansi.Vol. 11 No. 3. Desember 2009. Hal 189-207.

Jensen dan Meckling. (1976). Theory of the Firm:
Managerial Behavior, Agency Costs and Owner ship Structure. Jurnal of Financial Economics. V.3. No 4.p. 305-360.

Kasmir. (2014). Analisis Laporan Keuangan. Edisi Satu. Cetakan Ketujuh. Jakarta: PT Raja Grafindo Persada.

Margaretha, F. (2014). Determinants of Debt Policy in Indonesia's Public Company. Rev. Integr. Bus. Econ. Res. Vol 3(2), p. 10-16.

Murni, S. dan Andriana. (2007). Pengaruh Insider Owner ship, Institutional Investor, Dividend Payments dan Firm Growth Terhadap Kebijakan Hutang Perusahaan (Studi Kasus pada Perusah aan Manufaktur yang Terdaftar di Bursa Efek Jakarta). Jurnal Akuntansi dan Bisnis.Vol.7. No. 1.Februari.hlm. 15-24.

Nina, D. P. (2009). Pengaruh Faktor-faktor Intern Perusahaan terhadap Kebijakan Utang dengan pendekatan Pecking Order Theory. Universitas Lampung.

Rodoni, A. dan Ali, H. (2014) Manajemen Keuangan Modern. Jakarta: Mitra Wacana Media.

Saidi. (2004). Faktor-Faktor yang Mempengaruhi Struktur Modal pada Perusahaan Manufaktur Go Publik di Bursa Efek Jakarta Tahun 19972002. Jurnal Bisnis dan Ekonomi.Vol.11. No. 1.Maret.hlm. 44-58.

Sartono, R. A. (2001). Manajemen Keuangan: Teori dan Aplikasi. Edisi 4.Yogyakarta: BPFE. Simultan Nonliner dari Kepemilikkan Manajerial, Penerimaaan Risiko, Kebijakan Utang dan Kebijakan Dividen. Prosiding Simposium Nasional Akuntansi V, Semarang, 5-6 September, hlm. 601-623.

Steven dan Lina. (2011). Faktor-Faktor Yang Mempengaruhi Kebijakan Hutang Perusahaan Manufaktur. Jurnal Bisnis dan Akuntansi, Vol 13, No 3. Umi Narimawati. (2008). Teknik - Teknik Analisis Multivariat Untuk Riset Ekonomi. Yogyakarta: Graha Ilmu.

Sugiyono. (2015). Metode Penelitian Kuantitatif, Kualitatif dan $R$ dan D. Bandung: Alfabeta.

Sujoko; Soebiantoro, U. (2007). Pengaruh Struktur Kepemilikan, Leverage, Faktor Intern, dan Faktor Ekstern Terhadap Nilai Perusahaan (Studi Empirik pada Perusahaan Manufaktur dan Non Manufaktur di Bursa Efek Jakarta), 
Jurnal Manajemen dan Kewirausahaan, Vol. 9 No.1, Maret 2007.

Susanto, Y. K. (2011). Pengaruh Faktor-Faktor Intern Perusahaan Terhadap Kebijakan $\mathrm{Hu}-$ tang: Dengan Pendekatan Pecking Order Theory. Jurnal Bisnis dan Akuntansi, Vol. 13. No. 3. Hlm. 195-210.

Tjeleni, I. (2013). Kepemilikan Manajerial dan Institusional Pengaruhnya Terhadap Kebijakan Hutang Pada Perusahaan Manufaktur Di Bursa Efek Indonesia. Jurnal EMBA 129 Vol.1 No.3 September 2013 ISSN 2303-1174.

Tyas, L. T. (2003), Kepemilikkan Manajerial dan Pengaruhnya Terhadap Kepemilikkan Saham Institusional. Jurnal Politeknik Negeri Semarang Vol 3.

Vo, D.H, and V.T.Y. Nguyen. (2014). Managerial Ownership, Leverage and Dividend Politicies: Empirical evidence from Vietnam's Listed
Firms. International Journal of Economics and Finance, 6 (5), 274-284.

Wahidahwati. (2002). Kepemilikkan Manajerial dan Agency Conflicts: Analisis Persamaan Simultan Nonlinier dari Kepemilikkan Manajerial, Penerimaan Resiko (Risk Taking), Kebijakan Utang. Simposium Nasional Akuntansi Lima.

Wiliandri, R. (2011). Pengaruh Blockholder Ownership dan Firm Sizeterhadap Kebijakan Hutang Perusahaan. Jurnal Ekonomi Bisnis. Th. 2016 No.2. Juli. Hlm. 95-102.

Yeniatie dan Destriana, N. (2010). Faktor-Faktor yang Mempengaruhi Kebijakan Hutang pada Perusahaan Non keuangan yang Terdaftar di Bursa Efek Indonesia. Jurnal Bisnis dan Akuntansi. Vol. 12, No.1., April 2010, Hlm. 1-16. 